OPEN ACCESS

Edited by:

Si Zhang,

Fudan University, China

Reviewed by:

Rongrong Liu,

Northwestern University,

United States

Ming Zhao,

Capital Medical University, China

*Correspondence:

Lining Arnold Ju

arnold.ju@sydney.edu.au

Specialty section:

This article was submitted to Experimental Pharmacology and Drug

Discovery,

a section of the journal

Frontiers in Pharmacology

Received: 19 September 2021 Accepted: 28 December 2021 Published: 20 January 2022

Citation:

Zhang $Y$, Jiang $F$, Chen $Y$ and Ju LA (2022) Platelet Mechanobiology Inspired Microdevices: From Hematological Function Tests to

Disease and Drug Screening.

Front. Pharmacol. 12:779753.

doi: 10.3389/fphar.2021.779753

\section{Platelet Mechanobiology Inspired Microdevices: From Hematological Function Tests to Disease and Drug Screening}

\author{
Yingqi Zhang ${ }^{1,2,3}$, Fengtao Jiang ${ }^{1}$, Yunfeng Chen $^{4,5}$ and Lining Arnold $\mathrm{Ju}^{1,2,3 *}$ \\ ${ }^{1}$ School of Biomedical Engineering, Faculty of Engineering, The University of Sydney, Sydney, NSW, Australia, ${ }^{2}$ Charles Perkins \\ Centre, The University of Sydney, Camperdown, NSW, Australia, ${ }^{3}$ Heart Research Institute, Newtown, NSW, Australia, ${ }^{4}$ The \\ Department of Biochemistry and Molecular Biology, The University of Texas Medical Branch, Galveston, TX, United States, ${ }^{5}$ The \\ Department of Pathology, The University of Texas Medical Branch, Galveston, TX, United States
}

Platelet function tests are essential to profile platelet dysfunction and dysregulation in hemostasis and thrombosis. Clinically they provide critical guidance to the patient management and therapeutic evaluation. Recently, the biomechanical effects induced by hemodynamic and contractile forces on platelet functions attracted increasing attention. Unfortunately, the existing platelet function tests on the market do not sufficiently incorporate the topical platelet mechanobiology at play. Besides, they are often expensive and bulky systems that require large sample volumes and long processing time. To this end, numerous novel microfluidic technologies emerge to mimic vascular anatomies, incorporate hemodynamic parameters and recapitulate platelet mechanobiology. These miniaturized and cost-efficient microfluidic devices shed light on high-throughput, rapid and scalable platelet function testing, hematological disorder profiling and antiplatelet drug screening. Moreover, the existing antiplatelet drugs often have suboptimal efficacy while incurring several adverse bleeding side effects on certain individuals. Encouraged by a few microfluidic systems that are successfully commercialized and applied to clinical practices, the microfluidics that incorporate platelet mechanobiology hold great potential as handy, efficient, and inexpensive pointof-care tools for patient monitoring and therapeutic evaluation. Hereby, we first summarize the conventional and commercially available platelet function tests. Then we highlight the recent advances of platelet mechanobiology inspired microfluidic technologies. Last but not least, we discuss their future potential of microfluidics as point-of-care tools for platelet function test and antiplatelet drug screening.

Keywords: microfluidics, thrombosis, platelet, von Willebrand disease, mechanobiology, clopidogrel, aspirin, COVID-19

\section{INTRODUCTION}

In blood circulation, anucleate platelets are the smallest cells that play a central role in hemostasis (hemorrhage arrest upon vascular breach) and thrombosis (vessel occlusion with cessation of blood flow leading to tissue injury) (Rasche, 2001; Ruggeri, 2002; Colman, 2006). In line with the Virchow's triad (Bagot and Arya, 2008), platelet adhesion, activation and aggregation are significantly 
influenced by hemodynamic factors such as shear rate and shear stress (Yin et al., 2011; Sheriff et al., 2013). In pathologically relevant vascular anatomies including stenoses, aneurysms and bifurcations, platelet prothrombotic behaviors are further exacerbated by shear gradient (Nesbitt et al., 2009; Westein et al., 2013; Zhang and Neelamegham, 2017), vorticity (Varble et al., 2017), or turbulence (Nesbitt et al., 2009; Ha et al., 2018). At the molecular scale, increasing evidences suggest that platelets can undergo mechanosensing upon receiving these hemodynamic stimuli. Key players in such mechanosensing processes include von Willebrand factors (VWF) (Savage et al., 1996; Fu et al., 2017), fibrinogen (Butera and Hogg, 2020; Peshkova et al., 2020), mechanoreceptors including glycoprotein Ib (GPIb) (Chen et al., 2016; Ju et al., 2016) and glycoprotein IIb/IIIa (GPIIb/IIIa or integrin $\alpha_{\text {IIb }} \beta_{3}$ ) (Nesbitt et al., 2009; Chen Y et al., 2019), and mechanosensitive ion channels (Abbonante et al., 2017; Ilkan et al., 2017; Liu et al., 2021). Further, activated platelets generate contractile forces to stabilize and consolidate the thrombus (Osdoit and Rosa, 2001; Ono et al., 2008; Hansen et al., 2018). Abnormal platelet function can cause thrombosis (Chen and Ju, 2020), bleeding disorders (Castaman et al., 1997); Cines and Bussel, 2021; Lee et al., 2021; Pavord et al., 2021) and autoimmune diseases (Zoller et al., 2012). Diabetes, obesity and other metabolic syndromes are well known to be associated with platelet hyperactive functions and exhibit prothrombotic phenotypes (Podrez et al., 2007; Santilli et al., 2012; Ju et al., 2018). More recently, COVID-19 severe symptoms and thrombotic complications are demonstrated to associate with platelet dysfunctions (Manne et al., 2020; Koupenova et al., 2021).

Over the past decades, multiple platelet function tests-mainly grouped into biomarker-based assays, aggregometry and biomechanical-based assays-have been commercialized and standardized for diagnosis and monitoring of platelet (dys) function in clinical pathology laboratories and intensive care units (Yarovoi et al., 2003; Nesbitt et al., 2006; Furie et al., 2021). However, due to the requirement of large sample volumes and long processing time, these expensive and bulky techniques often have restricted application. More importantly, the hemodynamic microenvironment and platelet mechanobiology at play are insufficiently incorporated in these tests. While the existing biomechanical assays have incorporated the flow effect and viscoelasticity of platelet thrombi, they often have fixed physical constants and black boxes for external manipulation. To this end, more handy, efficient, and inexpensive point-of-care tools that can incorporate platelet mechanobiology promise more comprehensive and profound assessment of platelet function and the related hematological disorders (Paniccia et al., 2015).

With respect to antiplatelet medications, aspirin and triflusal (TxA2 generation blockers), clopidogrel, ticagrelor, ticlopidine and prasugrel (adenosine diphosphate (ADP) receptor $\mathrm{P}_{2} \mathrm{Y}_{12}$ blockers), dipyridamole and cilostazol (phosphodiesterase inhibitors), vorapaxar (PAR-1 antagonist), and warfarin (vitamin $\mathrm{K}$ antagonists) are the standards of care that target platelet functions for antithrombotic therapies (Dlott et al., 2014; Thachil, 2016; McFadyen et al., 2018). However, longstanding limitation of these agents is their inability to differentiate between hemostasis and thrombosis. Adverse side effects associated with these antiplatelet therapies can appear, including the increased risk of dose-dependent bleeding (by prasugrel and ticagrelor), thrombocytopenia (by heparin, prasugrel, ticlopidine), hypersensitivity (by clopidogrel, prasugrel, ticagrelor), acute kidney injury (by aspirin) and hypotension (by dipyridamole) (Walenga et al., 2012; McFadyen et al., 2018). Therefore, the dose and combination of antiplatelet prescription needs to be tailored carefully upon individuals (Koenig-Oberhuber and Filipovic, 2016). There is a strong driver for rapid, quantitative and accurate analytical tools that have utility with respect to patient-specific antiplatelet therapies, in other words, more effective antiplatelet precision medicine.

With recent advance of microfabrication technologies, a variety of microfluidic approaches emerge to mimic vascular anatomies, reconstitute hemodynamic factors and recapitulate platelet mechanobiology underlying hematological processes (Tovar-Lopez et al., 2010; Tsai et al., 2012; ZilbermanRudenko et al., 2017; Koupenova et al., 2018; Ting et al., 2019). Whilst clinical translation remains a pertinent issue, the miniaturized and cost-efficient microfluidic devices are the complementary avenues that allow rapid and high-throughput platelet function testing and antiplatelet drug screening. To date, several point-of-care microfluidic systems have gained FDA approvals for clot viscoelasticity assay $\left(\mathrm{TEG}^{\circledR}\right.$ 6s system), blood chemistry analysis (sodium, potassium, chloride, glucose, hematocrit, gases) and immune hematology tests (analytes concentration) (Chin et al., 2012; Sharma et al., 2015).

Hereby, we summarize the existing platelet function tests in the clinical domain, discuss their limitations, then review emerging microfluidic devices inspired by platelet mechanobiology and discuss their future point-of-care potentials.

\section{COMMERCIALLY AVAILABLE PLATELET FUNCTION TESTS AND THEIR CLINICAL USAGE}

Bleeding time (BT) evaluation appeared as the earliest platelet function test in clinical use (Duke, 1983). Serving as an in vivo testing, BT is invasive and has low reproducibility and specificity in the routine monitoring of antiplatelet therapies (Jakubowski et al., 2007). Recently, noninvasive and simpler in vitro platelet function tests become commercially available. We list these existing techniques in Table $1-A$ summary of the standardized platelet function tests, which could be broadly categorized into the following three groups:

1) Biomarker-based assessment. Platelet functional status are often depicted by their activation marker expression and metabolite secretion. Flow cytometry is commonly used to not only quantify platelet receptor expression such as GPIb (Adelman et al., 1985), but also depict platelet activation status via PAC-1 antibody binding (GPIIb/IIIa activation) (Ginsberg et al., 1990; Ju et al., 2018), P-selectin expression ( $\alpha$-granule secretion) (Kehrel and Brodde, 2013), annexin A5 binding 
TABLE 1 | A summary of conventional assays and the novel microfluidic devices for platelet function analysis and antiplatelet drug screening

\begin{tabular}{|c|c|c|c|c|c|c|c|}
\hline Analysis & Device & Measurement & $\begin{array}{c}\text { Clinical } \\
\text { implication }\end{array}$ & $\begin{array}{c}\text { Pharmacologic } \\
\text { monitor }\end{array}$ & Advantages & Limitations & References \\
\hline \multicolumn{8}{|c|}{ Commercial devices } \\
\hline $\begin{array}{l}\text { Biomarker } \\
\text { based }\end{array}$ & $\begin{array}{l}\text { Flow cytometry, } \\
\text { ELISA }\end{array}$ & $\begin{array}{l}\text { Platelet } \\
\text { activation } \\
\text { markers } \\
\text { quantification }\end{array}$ & $\begin{array}{l}\text { BSS/GT/HIT/ } \\
\text { Scott syndrome }\end{array}$ & $\begin{array}{l}\text { Aspirin, } \mathrm{P}_{2} \mathrm{Y}_{12} \\
\text { antagonists, heparin }\end{array}$ & $\begin{array}{l}\text { Small volume/ } \\
\text { independent of } \\
\text { platelet count }\end{array}$ & $\begin{array}{l}\text { Expensive/ } \\
\text { specialized training }\end{array}$ & $\begin{array}{l}\text { Muir et al. (2009), } \\
\text { Hezard et al. (2010), } \\
\text { Williams et al. (2010), } \\
\text { Pakala and } \\
\text { Waksman (2011), } \\
\text { Harrison and Keeling } \\
\text { (2012); Kehrel and } \\
\text { Brodde (2013); } \\
\text { Dahlen et al. (2013), } \\
\text { Gremmel et al. } \\
\text { (2013), Harrison and } \\
\text { Lordkipanidze } \\
\text { (2013), Guéry et al. } \\
\text { (2018) }\end{array}$ \\
\hline \multirow[t]{2}{*}{$\begin{array}{l}\text { Aggregom- } \\
\text { etry }\end{array}$} & 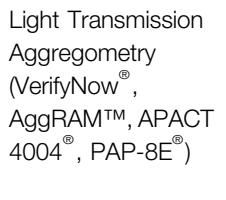 & Optical density & $\begin{array}{l}\text { ADP } \\
\text { accumulation } \\
\text { defect/BSS/Type } \\
\text { 2B WD/GT }\end{array}$ & $\begin{array}{l}\text { Aspirin, } \mathrm{P}_{2} \mathrm{Y}_{12} \text { and } \\
\text { GPIllb/llla antagonists }\end{array}$ & $\begin{array}{l}\text { Flexible/gold } \\
\text { standard }\end{array}$ & $\begin{array}{l}\text { Sample processing/ } \\
\text { large sample } \\
\text { volumes/lack HCT } \\
\text { consideration/not } \\
\text { sensitive to acquired } \\
\text { platelet defects }\end{array}$ & $\begin{array}{l}\text { Hayward et al. } \\
\text { (2009), Morel-Kopp } \\
\text { et al. (2010), Sibbing } \\
\text { et al. (2010), } \\
\text { Solomon et al. } \\
\text { (2010), Bolliger et al. }\end{array}$ \\
\hline & $\begin{array}{l}\text { Multiple Electrode } \\
\text { Aggregometry } \\
\text { (Multiplate }^{\circledR}, \\
\text { Chrono-Log }^{\boxplus} \text { ) }\end{array}$ & $\begin{array}{l}\text { Electrical } \\
\text { impedance }\end{array}$ & $\begin{array}{l}\text { Storage pool } \\
\text { disease/GT/ } \\
\text { WWD/COD/HIT }\end{array}$ & $\begin{array}{l}\text { Aspirin, } \mathrm{P}_{2} \mathrm{Y}_{12} \text { and } \\
\text { GPIllb/llla antagonists }\end{array}$ & $\begin{array}{l}\text { Simple/small } \\
\text { volume/flexible }\end{array}$ & $\begin{array}{l}\text { Limited HCT and } \\
\text { platelet count range/ } \\
\text { bulky/insensitive to } \\
\text { TRAP-induced } \\
\text { platelet aggregation }\end{array}$ & $\begin{array}{l}\text { (2012a), Tantry et al. } \\
\text { (2013), Paniccia } \\
\text { et al. (2015), Opheim } \\
\text { et al. (2019), Alessi } \\
\text { et al. (2020), Le } \\
\text { Blanc et al. (2020) }\end{array}$ \\
\hline \multirow[t]{4}{*}{$\begin{array}{l}\text { Biomechan- } \\
\text { ical based }\end{array}$} & $\begin{array}{l}\text { Shear flow-based } \\
\text { assays (PFA-100/ } \\
200^{\circledR} \text {, PlaCor } \text { PRT }^{\circledR} \text { ) }\end{array}$ & Occlusion time & $\begin{array}{l}\text { Type } 2 \text { WD/ } \\
\text { BSS/GT }\end{array}$ & $\begin{array}{l}\text { Aspirin, } \mathrm{P}_{2 \mathrm{Y}_{12}} \\
\text { antagonists }\end{array}$ & $\begin{array}{l}\text { Rapid/small } \\
\text { volume/simple/ } \\
\text { sensitive to } \\
\text { severe platelet } \\
\text { defects }\end{array}$ & $\begin{array}{l}\text { Insensitive to mild } \\
\text { platelet disorders/ } \\
\text { platelet count and } \\
\text { HCT dependent/ } \\
\text { irrelevant to stenotic } \\
\text { thrombosis }\end{array}$ & $\begin{array}{l}\text { Harrison et al. } \\
\text { (2002), Harrison } \\
\text { et al. (2011), } \\
\text { Johnson et al. } \\
\text { (2012), Gorog and } \\
\text { Jeong (2015) }\end{array}$ \\
\hline & $\begin{array}{l}\text { Cone and Plate (Let) } \\
\text { Analyzer } \\
\left(\text { Impact- }{ }^{\circledR}\right)\end{array}$ & $\begin{array}{l}\text { Surface } \\
\text { coverage and } \\
\text { aggregation size }\end{array}$ & $\begin{array}{l}\text { Type } 3 \text { WWD/GT/ } \\
\text { Afibrinogenemia }\end{array}$ & $\begin{array}{l}\text { Aspirin, GPIlb/Illa } \\
\text { antagonists, ADP } \\
\text { antagonists }\end{array}$ & $\begin{array}{l}\text { Automated/ } \\
\text { simple/rapid/ } \\
\text { small volume/ }\end{array}$ & $\begin{array}{l}\text { Expensive/ } \\
\text { specialized training/ } \\
\text { lack clinical studies }\end{array}$ & $\begin{array}{l}\text { Savion and Varon } \\
\text { (2006), Anand et al. } \\
\text { (2007), Shenkman } \\
\text { et al. (2008), } \\
\text { Paniccia et al. (2015) }\end{array}$ \\
\hline & $\begin{array}{l}\text { Thromboelasto- } \\
\text { graphy assay } \\
\left(\text { TEG }^{\circledast}, \text { ROTEM }^{\circledast} \text {, }\right. \\
\text { Sonoclot }^{\oplus} \text { ) }\end{array}$ & $\begin{array}{l}\text { Clot } \\
\text { viscoelasticity } \\
\text { upon torque } \\
\text { application }\end{array}$ & $\mathrm{ACT} / \mathrm{PPH}$ & $\begin{array}{l}\text { Heparin, aprotinin, } \\
\text { aspirin, GPIIb/Illa } \\
\text { antagonists, ADP } \\
\text { antagonists }\end{array}$ & $\begin{array}{l}\text { Complete clot } \\
\text { profile }\end{array}$ & $\begin{array}{l}\text { Interlaboratory } \\
\text { variation/time- } \\
\text { consuming/limited } \\
\text { platelet and HCT } \\
\text { count range/lack } \\
\text { clinical study/ } \\
\text { expensive }\end{array}$ & $\begin{array}{l}\text { Paniccia et al. } \\
\text { (2015), Mitrovic et al. } \\
\text { (2021), Moore et al. } \\
\text { (2021) }\end{array}$ \\
\hline & $\begin{array}{l}\text { Thromboelast- } \\
\text { ography assay } \\
\left(\text { TEG }^{\circledR} 6 s,\right. \\
\left.\text { Quantra }^{\circledR}\right)\end{array}$ & $\begin{array}{l}\text { Clot } \\
\text { viscoelasticity } \\
\text { upon resonance } \\
\text { application }\end{array}$ & $\begin{array}{l}\text { Trauma and } \\
\text { cardiac surgery }\end{array}$ & $\begin{array}{l}\mathrm{P}_{2} \mathrm{Y}_{12} \text { and } \mathrm{GPIlb} / \mathrm{Illa} \\
\text { antagonists }\end{array}$ & $\begin{array}{l}\text { High precision/ } \\
\text { fully automated/ } \\
\text { portable/multi- } \\
\text { channel/reduced } \\
\text { blood volume }\end{array}$ & $\begin{array}{l}\text { Lack clinical study/ } \\
\text { expensive }\end{array}$ & $\begin{array}{l}\text { (Ferrante et al., } \\
\text { 2016; Dias et al., } \\
\text { 2020; Lloyd-Donald } \\
\text { et al., 2020) }\end{array}$ \\
\hline
\end{tabular}

Microfluidic platforms

\begin{tabular}{|c|c|c|c|c|c|c|c|}
\hline \multirow[t]{2}{*}{$\begin{array}{l}\text { Shear } \\
\text { dependent } \\
\text { platelet } \\
\text { function test }\end{array}$} & Straight & Platelet adhesion & - & $\begin{array}{l}\mathrm{COX}-1, \mathrm{P} 2 \mathrm{Y} 1 \text { and } \\
\mathrm{P}_{2 \mathrm{Y}_{12}} \text { antagonists }\end{array}$ & $\begin{array}{l}\text { Controlled flow } \\
\text { rate/temporal and } \\
\text { spatial } \\
\text { observation }\end{array}$ & - & Li et al. (2017) \\
\hline & Stenosis & Clotting time & HPS/Sepsis/SCA & $\begin{array}{l}\text { COX, P2Y } 12 \text {, GPIlb/ } \\
\text { Illa antagonists } \\
\text { (aspirin, clopidogrel, } \\
\text { abciximab), Heparin }\end{array}$ & $\begin{array}{l}\text { High dynamic } \\
\text { range/real-time } \\
\text { monitoring and } \\
\text { quantification }\end{array}$ & $\begin{array}{l}\text { Non instantaneous } \\
\text { and continuous } \\
\text { (<20min) monitoring }\end{array}$ & Jain et al. (2016b) \\
\hline
\end{tabular}


TABLE 1 | (Continued) A summary of conventional assays and the novel microfluidic devices for platelet function analysis and antiplatelet drug screening.

\begin{tabular}{|c|c|c|c|c|c|c|c|}
\hline Analysis & Device & Measurement & $\begin{array}{c}\text { Clinical } \\
\text { implication }\end{array}$ & $\begin{array}{c}\text { Pharmacologic } \\
\text { monitor }\end{array}$ & Advantages & Limitations & References \\
\hline & & $\begin{array}{l}\text { Platelet } \\
\text { aggregation } \\
\text { surface and size }\end{array}$ & $\begin{array}{l}\text { Borderline type } 1 \\
\text { WWD; Type 2/ } \\
3 \text { WWD }\end{array}$ & $\begin{array}{l}\mathrm{T}_{X} \mathrm{~A} 2, \mathrm{P}_{2} \mathrm{Y}_{12} \text { and } \\
\mathrm{P} 2 \mathrm{Y} 1 \text { antagonists } \\
\text { (indomethacin, } \\
\text { 2-E11MeSAMP, } \\
\text { MRS2179) }\end{array}$ & $\begin{array}{l}\text { Real-time } \\
\text { monitoring/small } \\
\text { volume/sensitive } \\
\text { to low platelet } \\
\text { count }\end{array}$ & $\begin{array}{l}\text { Strict to ULWW } \\
\text { involved } \\
\text { aggregation }\end{array}$ & Brazilek et al. (2017) \\
\hline \multirow[t]{3}{*}{$\begin{array}{l}\text { Contractile } \\
\text { force analysis }\end{array}$} & Micropatterns & $\begin{array}{l}\text { Microdot area } \\
\text { and } \\
\text { displacement }\end{array}$ & WAS/MYH9RD & - & $\begin{array}{l}\text { Single cell } \\
\text { resolution/ } \\
\text { modulable } \\
\text { substrate } \\
\text { properties/high } \\
\text { throughput }\end{array}$ & $\begin{array}{l}\text { Cannot detect low } \\
\text { contraction }\end{array}$ & Myers et al. (2017) \\
\hline & Microposts & $\begin{array}{l}\text { Micropillar } \\
\text { deflection }\end{array}$ & $\begin{array}{l}\text { TIC/cardiology } \\
\text { patient on aspirin } \\
\text { medication }\end{array}$ & $\begin{array}{l}\mathrm{P}_{2 Y_{12}}, \mathrm{GPIb} / \mathrm{IIX}, \\
\text { GPIlb/Illa antagonists } \\
\text { (2-MeSAMP, AK2, } \\
\text { c7E3) }\end{array}$ & $\begin{array}{l}\text { No additional } \\
\text { agonist required/ } \\
\text { No sample } \\
\text { preparation/ } \\
\text { sensitive }\end{array}$ & - & $\begin{array}{l}\text { Ting et al. (2013), } \\
\text { Ting et al. (2019), } \\
\text { Miles et al. (2021) }\end{array}$ \\
\hline & & & Type 2A WWD & $\begin{array}{l}\text { GPIba, GPIlb/llla } \\
\text { antagonists (HIP1, } \\
\text { abciximab) }\end{array}$ & $\begin{array}{l}\text { Real-time/ } \\
\text { medium } \\
\text { throughput/clot } \\
\text { stiffness } \\
\text { measurement }\end{array}$ & - & Chen Z et al. (2019) \\
\hline \multirow[t]{2}{*}{$\begin{array}{l}\text { Integrated } \\
\text { drug } \\
\text { screening } \\
\text { system }\end{array}$} & SpearChip & Platelet adhesion & - & $\begin{array}{l}\text { GPIlb/llla and P2Y } 12 \\
\text { antagonists } \\
\text { (abciximab, } \\
\text { clopidogrel, } \\
\text { prasugrel, ticagrelor, } \\
\text { cangrelor) }\end{array}$ & $\begin{array}{l}\text { Self-powered/no } \\
\text { dead volume/ } \\
\text { reproducible }\end{array}$ & $\begin{array}{l}\text { Flow controlled by } \\
\text { chip design }\end{array}$ & Jose et al. (2016) \\
\hline & Micropump-Mixer & $\begin{array}{l}\text { Thrombus } \\
\text { volume }\end{array}$ & - & $\begin{array}{l}\text { PI3K inhibitors } \\
\text { (AS2524224, } \\
\text { TGX221, LY294002, } \\
\text { Wortmannin) }\end{array}$ & $\begin{array}{l}\text { High integration/ } \\
\text { high throughput/ } \\
\text { automated/short } \\
\text { incubation time/ } \\
\text { small dead } \\
\text { volumes }\end{array}$ & - & Szydzik et al. (2019) \\
\hline
\end{tabular}

BSS, Bernard-Soulier syndrome; GT, Glanzmann's thrombasthenia; HIT, Heparin-induced thrombocytopenia; COD, Cyclooxygenase deficiency; ATC, Acute trauma coagulopathy; PPH, Postpartum hemorrhage; HPS, Hermansky-Pudlak syndrome; SCA, sickle cell anemia; WAS, Wiskott-Aldrich; MYH9RD, MYH9-related disorders; TIC, Trauma-induced coagulopathy; WWD, von Willebrand disease; HCT: hematocrit.

(phosphatidylserine exposure) (Reddy et al., 2018), and vasodilator-stimulated phosphoprotein-phosphorylation (P2Y 12 activation) (Hezard et al., 2010; Williams et al., 2010; Harrison and Keeling, 2012; Kehrel and Brodde, 2013; Dahlen et al., 2013; Harrison and Lordkipanidze, 2013; Paniccia et al., 2015; Reddy et al., 2018). The related deficiency and mutation can be quickly identified by flow cytometry and linked to platelet disorders such as Bernard-Soulier syndrome (BSS) (GPIb), Glanzmann's thrombasthenia (GT) (GPIIb/IIIa) and platelet storage pool diseases such as gray platelet syndrome ( $\alpha$-granule).

Besides, measurement of thromboxane metabolites $\left(\mathrm{T}_{\mathrm{X}} \mathrm{A} 2\right)$ allows evaluation of platelet activation using ligand-binding assays such as radioimmunoassay (Rogasi et al., 1988), immunoradiometric assays (Shen and Tai, 1986), or enzyme-linked immunoassays (ELISA) (Muir et al., 2009; Gremmel et al., 2013). The LabCorp Serotonin Release
Assay is considered as the gold standard for diagnosing heparin-induced thrombocytopenia (HIT) (Guéry et al., 2018). While these biomarker-based assays use small sample volumes and can be independent on platelet counts, they are generally time-consuming, expensive, and require specialized operators and core facilities.

2) Aggregometry assays. There are mainly two types of platelet aggregation measurement-Light Transmission Aggregometry (LTA) (Alessi et al., 2020) and Multiple Electrode Aggregometry (MEA) (Opheim et al., 2019). LTA is the gold standard platelet function test that observes the increase of light transmission through the platelet-rich plasma (PRP) or washed platelet sample due to the convergence of individual platelets into aggregates; whereas MEA evaluates the electrical impedance proportional to platelet aggregation (Paniccia et al., 2015). There are a few LTA (VerifyNow ${ }^{\circledR}, \operatorname{AggRAM}^{\circledR}$, 
APACT $4004^{\circledR}$, PAP-8E ${ }^{\circledR}$ ) and MEA (Multiplate ${ }^{\circledR}$, ChronoLog ${ }^{\circledR}$ ) currently available for disease screening (storage pool disease, HIT, GT, BSS, von Willebrand disease (VWD), ADP accumulation defects or cyclooxygenase deficiency) (Morel-Kopp et al., 2010; Bolliger et al., 2012a; Tantry et al., 2013; Opheim et al., 2019; Alessi et al., 2020) and antiplatelet drug monitoring (aspirin, $\mathrm{P}_{2} \mathrm{Y}_{12}$ and GPIIb/IIIa antagonists) (Sibbing et al., 2010; Solomon et al., 2010; Le Blanc et al., 2020).

Nevertheless, these aggregometries present a few limitations. For example, LTA has less pronounced sensitivity to acquired platelet defects (Hayward et al., 2009), and MEA has not yet been able to distinguish those not responding to antiplatelet drugs and at risk of major adverse cardiovascular events (Paniccia et al., 2015).

3) Biomechanical platelet function assays. Biomechanical tests can be broadly grouped into shear flow -based assays [PFA$100 / 200^{\circledR}$, PlaCor PRT ${ }^{\circledR}$ (Johnson et al., 2012)], Cone and Plate(let) Analyzer (CPA) [Impact- ${ }^{\circledR}$ (Savion and Varon, 2006)], and thromboelastography assays [TEG ${ }^{\circledR}$ (Korpallova et al., 2018), ROTEM ${ }^{\circledR}$ (Bolliger et al., 2012b; Zaky, 2017), Sonoclot $^{\circledR}$ (Ganter and Hofer, 2008), TEG ${ }^{\circledR}$ 6s (Lloyd-Donald et al., 2020), Quantra ${ }^{\circledR}$ system (Ferrante et al., 2016)].

PFA-100/200 ${ }^{\circledR}$ and PlaCor PRT ${ }^{\circledR}$ measure the occlusion time after exposing platelets to a constant shear rate at $5,000 \mathrm{~s}^{-1}$ and $1,500 \mathrm{~s}^{-1}$, respectively (Gorog and Jeong, 2015). PFA-100/200 ${ }^{\circledR}$ immobilizes exogenous antagonists on a solid cartridge for platelet activation while PlaCor PRT $^{\circledR}$ activates platelets by inducing high shear in a narrowed aperture with a spring (Godino et al., 2014). These shear flow-based assays can distinguish type 2 VWD, BSS and GT but not mild platelet defects such as Hermansky-Pudlak syndrome (HPS), storage pool and release defects, type $1 \mathrm{VWD}$ and macrothrombocytopenia (Harrison et al., 2002; Harrison et al., 2011). CPA assesses adhering platelets subjected to shear forces imposed by the spinning cone on a plate. This system is useful to monitor type 3 VWD and examine dual antiplatelet drug efficiency but need to be further verified for inherited and acquired platelet dysfunction diagnosis (Savion and Varon, 2006; Anand et al., 2007; Shenkman et al., 2008; Paniccia et al., 2015).

Not specific to platelet function analysis, the thromboelastography is a global hemostatic function assay that evaluates viscoelastic variations of clot retraction (both platelet aggregation and fibrin polymerization) to diagnose coagulopathies (e.g., hypofibrinogenemia, platelet dysfunction) (Da Luz et al., 2014), predict bleeding risks (Stravitz, 2012), and determine need for transfusion (Paniccia et al., 2015). Nevertheless, thromboelastography assays may have two major limitations: 1) baseline measurements prior to treatment are required for reference; and 2) single platelet mechanosensing phenotypes are masked by high amounts of thrombin generated and the subsequent clot retraction (Moore et al., 2021).

\section{NOVEL MICROFLUIDIC APPROACHES FOR PLATELET FUNCTION ASSESSMENT AND ANTI-PLATELET DRUG SCREENING}

While the aforementioned commercial platelet function tests have been broadly used in clinical practices, emerging microfluidic approaches demonstrate several advantages:

1) Microfluidics can emulate physiologically relevant vascular anatomies. Conventional methods such as PFA-100/200 ${ }^{\circledR}$ do not capture the geometric characteristics of the vessel, preventing the mimicking of platelet responses to their microenvironment. In contrast, latest soft lithography enables multifaceted, high-fidelity and customized microfluidic designs to imitate various vascular anatomies, such as straight (Jain et al., 2016b; Li et al., 2017; Zhang and Neelamegham, 2017; Albers et al., 2019; Dupuy et al., 2021), bifurcated (Tsai et al., 2012), stenosed (Tovar-Lopez et al., 2010; Jain et al., 2016b) and net (Zilberman-Rudenko et al., 2017; Zhang et al., 2021) channels.

2) Microfluidics can recapitulate hemodynamic microenvironment. It is almost impossible for conventional platelet function tests to encapsulate the rheological parameters experienced by the platelets. Even for the PFA$100 / 200^{\circledast}$, pre-exposure to exogenous agonists hinders them to fully recapitulate the synergistic effects of chemical (released endogenously by activated platelets) and mechanical factors (shear stress, shear gradients, vorticity) (Panzer and Jilma, 2011). By mediating the geometries and flow input, microfluidic approaches have great control on the hemodynamic parameters which can be predicted when combined with computational fluid dynamics (CFD) simulation (Zhao et al., 2021).

3) Microfluidics have higher sensitivity in detecting certain platelet mechanobiology relevant disorders. While sometimes not readily and obviously diagnosed by the existing platelet function tests, HPS, VWD, Wiskott-Aldrich syndrome and MYH9-related disorders can be effectively detected with a few platelet mechanobiology inspired microfluidics (Jain et al., 2016b; Brazilek et al., 2017; Myers et al., 2017; Chen Z et al., 2019; Ting et al., 2019).

4) Microfluidics present better biomimetic performance. Endothelialized microfluidics are rapidly evolving as humanized screening platforms (Albers et al., 2019; Jenny et al., 2020; Dupuy et al., 2021). Increasing evidences demonstrate their great potential in simulating the interplays between platelets and circulatory systems (Zhang et al., 2021).

5) Existing platelet function tests are bulky, expensive, and require specialized operators and a large volume of blood samples. In sharp contrast, microfluidic devices are cheap in terms of both materials and fabrication process. These miniaturized microdevices are in sub-millimeter dimension (Chiu et al., 2017), which only require a small volume of blood sample in the scale of microliters (Convery and Gadegaard, 2019) to render reliable results. More recently, the integrated microfluidics with micro-pumps and mixers enable high-throughput, automated 

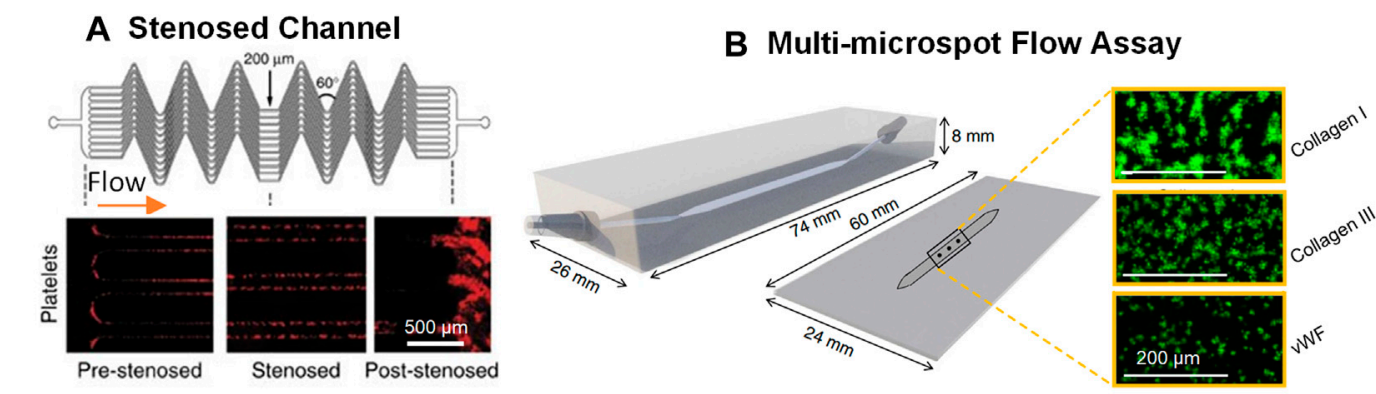

\section{Block-post Contractile Sensor}

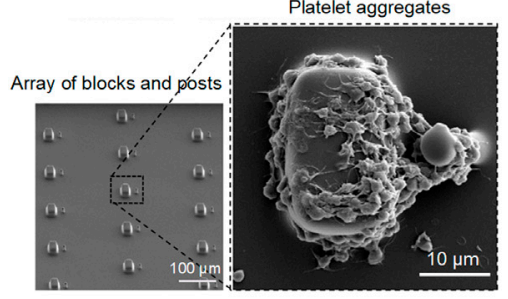

\section{F Chaotic Mixer}
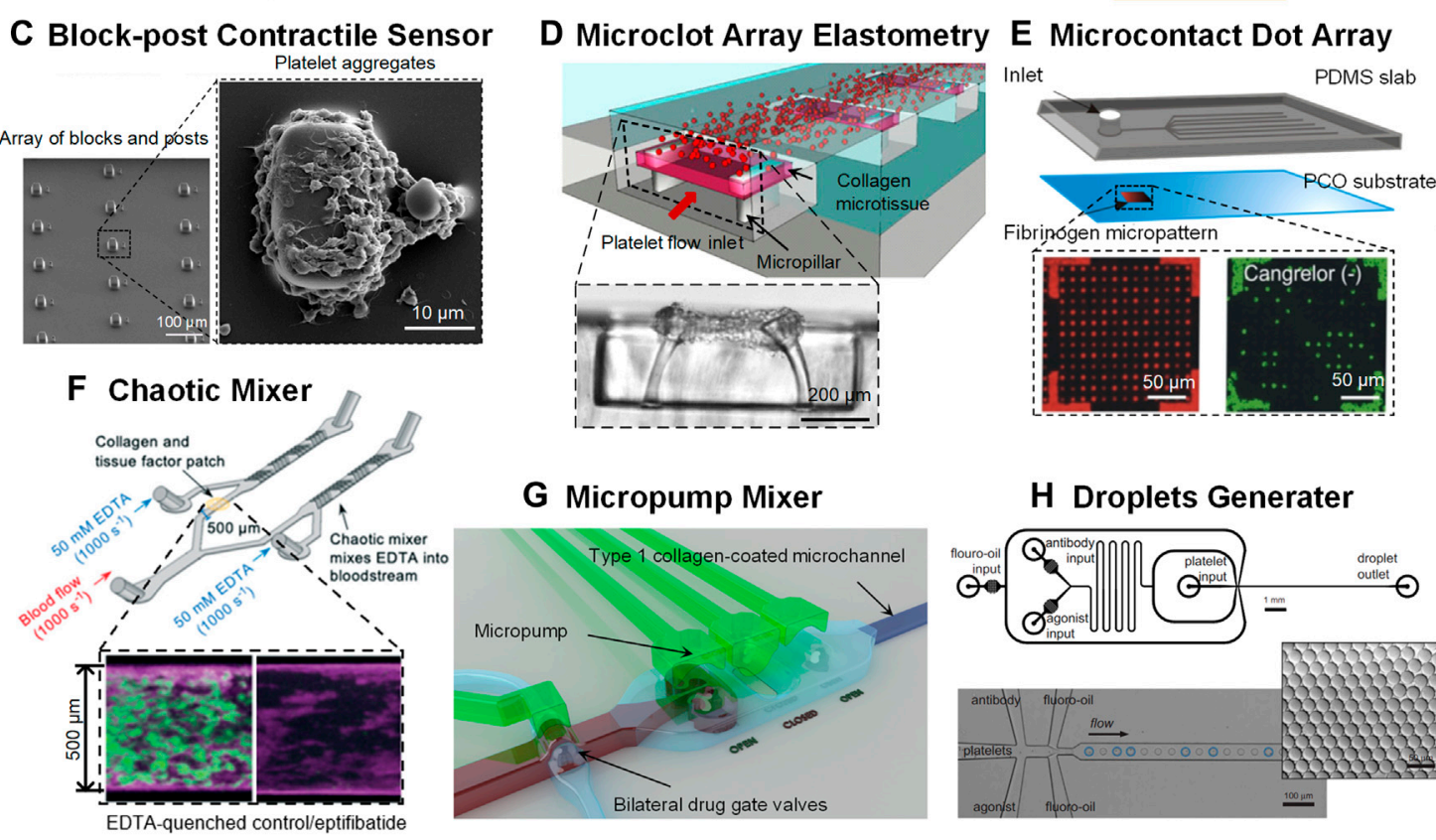

G Micropump Mixer

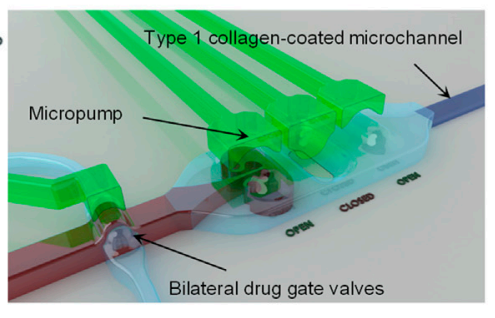

H Droplets Generater

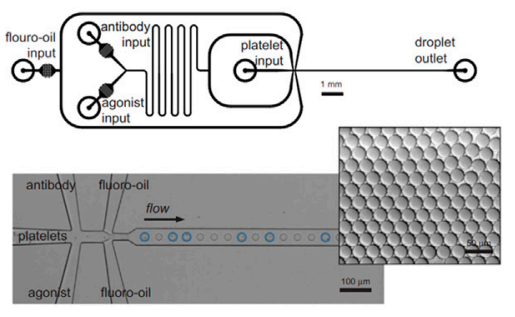

FIGURE 1 | Novel microfluidic platforms as point-of-care test of platelet function and anti-platelet drug screening. (A) A network of parallel stenosed microchannels which contain multiple regions of pre-stenosis, stenosis and post-stenosis from Jain et al. (2016a). (B) A multi-microspot microfluidic flow system from de Witt et al. (2014); Zoom-in: thrombi formed on the collagenNWF microspot surfaces. Scale bar $=200 \mu \mathrm{m}$. (C) Block-post contractile sensor from Ting et al. (2013), Ting et al. (2019); Left: SEM micrograph of an array of blocks and posts. Scale bar $=100 \mu \mathrm{m}$; Right: SEM micrograph of a platelet aggregate formed after $45 \mathrm{~s}$ at $8,000 \mathrm{~s}^{-1}$. Scale bar $=10 \mu \mathrm{m}$. (D) A microclot array elastometry system from Chen Z et al. (2019); Top: An array of exposed collagen microtissues capturing the flowing platelets to form individual microclots; Bottom: Sideview of a microtissue after platelet-mediated contraction. Scale bar $=200 \mu \mathrm{m}$. (E) The microcontact printed dot arrays from Jose et al. (2016); Top: Schematic of the microfluidic assembly; Bottom: Fluorescence images of 6- $\mu m$ Cy-3-labeled fibrinogen-dot arrays (red dots) and of FITC-labeled platelets (green dots) adhering to the fibrinogen dot arrays. Scale bar $=50 \mu \mathrm{m}$. (F) A chaotic mixer from Berry et al. (2021); Top: Schematic of the chaotic mixer; Bottom: Confocal images of platelets (and leukocytes) and fibrin in EDTA-quenched channel (left) and the eptifibatide channel (right). (G) An active micropump mixer with micropump valve chambers and pneumatic actuation chambers from Szydzik et al. (2019). (H) Droplet microfluidics from Jongen et al. (2020); Top: Schematic of the droplet generator design. Scale bar $=1 \mathrm{~mm}$. Bottom: Monodisperse droplets encapsulating platelets. Scale bar $=100 \mu \mathrm{m}$. Zoom-in: droplet monodispersity is indicated by hexagonal packaging. Scale bar $=50 \mu \mathrm{m}$.

disease and drug screening in much shorter turnaround time (Mayr and Bojanic, 2009; Szydzik et al., 2019).

In the following three subsections and Table 1, we summarized novel microfluidic platforms as the potential point-of-care tests of platelet function and antiplatelet drug screening.

\section{Shear Dependent Platelet Mechanobiology Inspired Microfluidics}

A range of microfluidic devices that recapitulate physiological and pathological hemodynamic microenvironment have been employed for platelet thrombosis and hematological studies (Gutierrez et al., 2008; Tovar-Lopez et al., 2010; Conant et al., 2011; Costa et al., 2017; Menon et al., 2020). The newly obtained platelet mechanobiology have further inspired novel microfluidic designs for diagnosis of platelet function disorders and patient profiling (Myers et al., 2017; Chen Z et al., 2019).

The earlier study of the shear dependent platelet mechanobiology utilized the simple straight channel with rectangular cross-section which can be easily fabricated by standard soft lithography. Gutierrez et al. (2008) developed two PDMS microfluidics devices with small cross section areas, thereby reducing the blood volume required $\left(<100 \mu \mathrm{l}\right.$ per assay) under a range of shear rates $\left(13-1,310 \mathrm{~s}^{-1}\right)$. 
Further, Li et al. (2017) applied an eight-channel microfluidic device coated with collagen to test the efficacy, dosage response, and combined antiplatelet therapeutic outcomes. The effectiveness of antiplatelet drugs (P2Y, COX-1 and kinase inhibitors) was tested on whole blood obtained from healthy individuals under the shear rates of $200 \mathrm{~s}^{-1}$ and $1,000 \mathrm{~s}^{-1}$. Similarly, Rossi and Diamond (2020) designed an injection-molded microfluidic device with a collagen/ tissue factor-printed surface to evaluate the dose response of anticoagulants (dabigatran, rivaroxaban, apixaban).

With recent microfabrication advancement, pathological microvascular geometries were incorporated into microfluidic channels to recapitulate flow disturbance and examine shear gradient effects on platelet thrombotic functions (Tovar-Lopez et al., 2010). Notably, Jain et al. developed a stenosed arteriolemimicking microfluidics that consists of three regions: 1) prestenosed region with sudden fluid acceleration; 2) stenosed region with uniform shear; 3) post-stenosed region with abrupt flow deceleration (Figure 1A) (Jain et al., 2016a). Remarkably, such microdevice was able to measure hemostatic defects of patients with HPS. The platelet defect in HPS patients is not commonly detectable by conventional PFA-100 and bleeding time assays (Harrison et al., 2011). Additionally, Brazilek et al. (2017) presented a micro-contraction device where $80^{\circ}$ doublestenosed test segments were designed. This stenosis microchannel not only can detect the reduction of biomechanical platelet aggregation as implicated in patients with type 1, 2 and 3 VWD, but also can distinguish the borderline type 1 VWD from the severe one. Interestingly, this microdevice gave better diagnostic outcomes in type 1 VWD patients than PFA-100 assay. One of the reason may be that the defective phenotypes of shear-dependent VWF-platelet mechanobiology is masked by the potent platelet preactivation in the exogenous agonists coated cartridges in PFA100 (Ardillon et al., 2015; Favaloro, 2015).

Other complexed vasculature mimicking systems have been developed, such as bifurcation microchannels (Tsai et al., 2012; Mao et al., 2021), vascular inflammatory model (Johnston et al., 2020) and bleeding model ( $\mathrm{Hu}$ et al., 2021). These innovative microfluidic platforms are capable of recapitulating not only the pathological shear but also the vascular biological functions for thrombosis, hemostasis and thromboinflammation studies and platelet function tests and drug screening. Moreover, de Wett et al. introduced a multi-microspot microfluidic flow system made of 52 platelet adhesive proteins and eight output parameters to characterize thrombus formation under wall shear rates at $150 \mathrm{~s}^{-1}$ and $1,600 \mathrm{~s}^{-1}$ (Figure 1B) (de Witt et al., 2014). Strikingly, the system has been applied to reveal abnormal thrombus formation in patients with severe combined immune deficiency, GT, HPS, May-Hegglin anomaly or gray platelet syndrome.

\section{Microfluidic Devices That Gauge Platelet Contractile Force}

Decreased platelet contractility is associated with the abnormal mechanics of blood clots. Several studies have confirmed the high relevance of platelet contractile forces to platelet aggregation and the subsequent hemostasis ( $\mathrm{Li}$ and $\mathrm{Li}, 2006$; Muthard and Diamond, 2012; Muthard and Diamond, 2013; Ting et al., 2013; Chen Z et al., 2019; van Rooij et al., 2020). Lam et al. (2011) customized a side-view atomic force microscope (AFM) to measure the contractile force of a single platelet encapsulated between the fibrinogen-coated cantilever and surface. Moreover, DNA-based tension probes are emerging as novel nanotechnology to measure platelet traction force by quantifying the threshold force required to unfold the immobilized DNA hairpins that links to platelet integrin receptors (Dutta et al., 2018; Zhang et al., 2018; Zhao et al., 2019).

While the existing AFM and DNA tension probes do not directly recapitulate hemodynamic effects, Hanke et al. (2019) introduced a microfluidic chamber integrated with traction force microscopy to quantify platelet contraction when exposed to shear. Specifically, a polyacrylamide hydrogel encapsulated with fluorescent beads was attached to the bottom of the microfluidic chamber. By measuring the displacement of substrates indicated by fluorescence beads, one can measure the platelet contractile forces under shear.

Further, Myers et al. (2017) developed a high-throughput platelet contraction cytometry that is capable of evaluating platelet contractile forces at single-cell resolution. This microfluidic device is composed of three layers: 1) a bottom cover slip; 2) a laser cut PDMS gasket filled with fibrinogen microdots-patterned hydrogel; and 3) a microfluidic flow chamber with inlet and outlet. In this model, single platelet contractility is directly associated with the area and displacement of fibrinogen microdot. Notably, patients suffering from Wiskott-Aldrich syndrome or MYH9-related disorders were identified to lack highly contractile platelets (Myers et al., 2017) and clot contraction (Godwin and Ginsburg, 1974; Shcherbina et al., 2010). However, one limitation of this device is that low contractile platelets are not detectable and therefore optimization is needed for more profound platelet contractility analysis.

In addition to single-cell level measurement, Ting et al. examined platelet contractility based on platelet aggregation using a microfluidic device with an array of rectangular microblocks paired with flexible microposts (Figure 1C) (Ting et al., 2013; Ting et al., 2019). Platelet contractile forces can be quantified based on the deflections of the microposts. Measurement of platelet contractile forces could help differentiate healthy individuals from patient-specific conditions, for example, cardiology patients on antiplatelet (aspirin) medications or trauma-induced coagulopathy patients at risk of bleeding. Besides, Chen et al. introduced a microclot array elastometry system consisting of three layers: 1) a microchannel on top; 2) collagen microtissues formed on PDMS micropillars in the intermediate layer; 3) stretchable silicone membrane on the bottom layer to allow micropillar deflection for clot contraction measurement (Figure 1D) (Chen Z et al., 2019). Such system has been used to not only test platelet contractility in response to antiplatelet agents, but also distinguish clot mechanics for health individuals from those with VWD. In short, the microfluidic systems of contractility measurement have demonstrated great potential in identifying 
platelet function disorders and giving additional anti-thrombotic therapeutic instruction.

\section{Highly Integrated Microfluidic Systems for Antiplatelet Drug Screening}

To enable efficient and accurate antiplatelet drug screening from a large library in the presence of hemodynamic microenvironment, the microsystem should include the following characteristics: 1) cheap and easy-to-use with small volume requirement of blood samples; 2) Simple and userfriendly operation; 3) accurate and rapid testing; 4) highthroughput to test a large number of drug candidates (Meagher et al., 2008; Gubala et al., 2012; Myers et al., 2017; Berry et al., 2021). Hereby we reviewed several integrated and multiplexed microfluidic systems that meet these requirements, demonstrating great potentials towards rapid, automated and high-throughput antiplatelet drug screening.

Jose et al. (2016) designed an automated microfluidic device consisting of a PDMS layer with microchannels and a cyclic olefin polymer base printed with microcontact dot arrays (Figure 1E). The device achieves self-powered vacuum-driven flow by exposing the pre-degassed PDMS in the air. Here, dot array occupancy indicates platelet adhesion and the system has been used to screen GPIIb/IIIa and P2 $\mathrm{Y}_{12}$ antagonists. Moreover, Berry et al. (2021) designed an occlusive thrombosis-on-a-chip model that incorporates two branching channels-a chaotic mixer for testing the EDRA quenching effects on platelet activation, and a collagen/tissue factor-coated channel for coagulation evaluation (Figure 1F). This model is simple and robust to measure occlusion time and can be utilized to screen potent antiplatelet drugs that inhibits channel occlusion and presumably blood vessel occlusion. Similarly, Szydzik et al. (2019) designed a novel active micropump mixer consisting of a pneumatic actuation chamber and a flow chamber separated by a thin diaphragm (Figure 1G). The micropump mixer enabled integration of sample preparation, drug incubation, blood mixing, and thrombus quantification on a single chip for antiplatelet drug screening.

Furthermore, Jongen et al. (2020) combined droplet microfluidics with flow cytometry for high-throughput single platelet function analysis (Figure 1H). The device incorporated four individual inlets to infuse platelets, agonist/antagonist solution and fluoro-oil, which eventually encountered at a common junction where analytes were encapsulated within the fluoro-oil droplets. Standard flow cytometry was then used to monitor droplet retrieved platelets' response to convulxin-the agonist to platelet receptor glycoprotein VI. Besides, Hao et al. developed a platelet detection microfluidics that integrates chemotherapeutic agents, tumor cells, endothelial cells and the flow rates to predict platelet responsiveness from cancer patients before or during chemotherapy (Hao et al., 2021). The microsystem contained a drug concentration generator, cancer cell culture chips, and three-dimensional circular microchannels lined with confluent endothelial layers. Taken together, these highly integrated microdevices exhibit great potentials for scalable point-of-care application.

\section{CONCLUSION}

Platelet mechanobiology inspired microfluidics are emerging technologies for rapid, robust, high-throughput thrombotic disease diagnosis and antiplatelet drug screening. Compared with the existing commercial platelet function tests, these microsystems are inexpensive and miniaturized, require small sample volume and have short processing time. As the manufacturing industry is rapidly advancing with respect to design standardization, operating procedure, analytical integration, we foresee that the microfluidic devices will evolve as not only cost-effective alternatives for basic platelet biology and anti-thrombotic pharmaceutical research, but also point-of-care and telehealth microdevices in cardiovascular patient management.

\section{AUTHOR CONTRIBUTIONS}

$\mathrm{YZ}$ and LJ conceived the study and wrote the manuscript. $\mathrm{YZ}$ and FJ co-wrote the manuscript. YC and LJ provided critical comments and supervised the study. All authors contributed to the article and approved the submitted version.

\section{FUNDING}

This work was supported by the Australian Research Council (ARC) Discovery Project (DP200101970-LJ), the National Health and Medical Research Council (NHMRC) of Australia Ideas Grant (APP2003904-LJ), NSW Cardiovascular Capacity Building Program (Early-Mid Career Researcher Grant-LJ), Sydney Research Accelerator prize (SOAR-LJ), NSW CVRN-VCCRI Research Innovation Grant and Ramaciotti Foundations Health Investment Grant (2020HIG76-LJ), Charles Perkins Centre Early to Mid-Career Researcher Seed Funding Grant (EMCR-YZ), Cardiovascular Initiative Catalyst Award seed funding (CVI-YZ), the National Heart, Lung, and Blood Institute Grant (HL153678-YC). Lining Arnold Ju is an ARC DECRA fellow (DE190100609).

\section{ACKNOWLEDGMENTS}

We thank Renee Ellen Preketes-tardiani, Savindi De Zoysa Ramasundara, Vivian Cheng, Hongxu Lu for the helpful discussion. We acknowledge Sydney Manufacturing Hub, Research Prototype Foundry under the Core Research Facility at the University of Sydney for support of our lab startup. 


\section{REFERENCES}

Abbonante, V., Di Buduo, C. A., Gruppi, C., De Maria, C., Spedden, E., De Acutis, A., et al. (2017). A New Path to Platelet Production through Matrix Sensing. Haematologica 102, 1150-1160. doi:10.3324/haematol.2016.161562

Adelman, B., Michelson, A. D., Handin, R. I., and Ault, K. A. (1985). Evaluation of Platelet Glycoprotein Ib by Fluorescence Flow Cytometry. Blood 66, 423-427. doi:10.1182/blood.v66.2.423.423

Albers, H. J., Passier, R., Van Den Berg, A., and Van Der Meer, A. D. (2019). Automated Analysis of Platelet Aggregation on Cultured Endothelium in a Microfluidic Chip Perfused with Human Whole Blood. Micromachines (Basel) 10 (11), 781. doi:10.3390/mi10110781

Alessi, M. C., Sié, P., and Payrastre, B. (2020). Strengths and Weaknesses of Light Transmission Aggregometry in Diagnosing Hereditary Platelet Function Disorders. J. Clin. Med. 9 (3), 763. doi:10.3390/jcm9030763

Anand, S. X., Kim, M. C., Kamran, M., Sharma, S. K., Kini, A. S., Fareed, J., et al. (2007). Comparison of Platelet Function and Morphology in Patients Undergoing Percutaneous Coronary Intervention Receiving Bivalirudin versus Unfractionated Heparin versus Clopidogrel Pretreatment and Bivalirudin. Am. J. Cardiol. 100, 417-424. doi:10.1016/j.amjcard.2007.02.106

Ardillon, L., Ternisien, C., Fouassier, M., Sigaud, M., Lefrançois, A., Pacault, M., et al. (2015). Platelet function analyser (PFA-100) results and von Willebrand factor deficiency: a 16-year 'real-world' experience. Haemophilia 21, 646-652. doi:10.1111/hae.12653

Bagot, C. N., and Arya, R. (2008). Virchow and His Triad: a Question of Attribution. Br. J. Haematol. 143, 180-190. doi:10.1111/j.13652141.2008.07323.x

Berry, J., Peaudecerf, F. J., Masters, N. A., Neeves, K. B., Goldstein, R. E., and Harper, M. T. (2021). An "occlusive Thrombosis-On-A-Chip" Microfluidic Device for Investigating the Effect of Anti-thrombotic Drugs. Lab. Chip 21 (21), 4104-4117. doi:10.1039/d1lc00347j

Bolliger, D., Dell-Kuster, S., Seeberger, M. D., Tanaka, K. A., Gregor, M., Zenklusen, U., et al. (2012a). Impact of loss of high-molecular-weight von Willebrand factor multimers on blood loss after aortic valve replacement. $\mathrm{Br}$. J. Anaesth. 108, 754-762. doi:10.1093/bja/aer512

Bolliger, D., Seeberger, M. D., and Tanaka, K. A. (2012b). Principles and Practice of Thromboelastography in Clinical Coagulation Management and Transfusion Practice. Transfus. Med. Rev. 26, 1-13. doi:10.1016/j.tmrv.2011.07.005

Brazilek, R. J., Tovar-Lopez, F. J., Wong, A. K. T., Tran, H., Davis, A. S., Mcfadyen, J. D., et al. (2017). Application of a strain rate gradient microfluidic device to von Willebrand's disease screening. Lab. Chip 17, 2595-2608. doi:10.1039/ c7lc00498b

Butera, D., and Hogg, P. J. (2020). Fibrinogen Function Achieved through Multiple Covalent States. Nat. Commun. 11, 5468. doi:10.1038/s41467-020-19295-7

Castaman, G., Yu-Feng, L., Battistin, E., and Rodeghiero, F. (1997). Characterization of a Novel Bleeding Disorder with Isolated Prolonged Bleeding Time and Deficiency of Platelet Microvesicle Generation. Br. J. Haematol. 96, 458-463. doi:10.1046/j.1365-2141.1997.d01-2072.x

Chen, W., Liang, X., Syed, A. K., Jessup, P., Church, W. R., Ware, J., et al. (2016). Inhibiting GPIba Shedding Preserves Post-Transfusion Recovery and Hemostatic Function of Platelets after Prolonged Storage. Arterioscler Thromb. Vasc. Biol. 36, 1821-1828. doi:10.1161/ATVBAHA.116.307639

Chen, Y., Ju, L. A., Zhou, F., Liao, J., Xue, L., Su, Q. P., et al. (2019). An Integrin aIIb $\beta 3$ Intermediate Affinity State Mediates Biomechanical Platelet Aggregation. Nat. Mater. 18, 760-769. doi:10.1038/s41563-019-0323-6

Chen, Y., and Ju, L. A. (2020). Biomechanical Thrombosis: the Dark Side of Force and Dawn of Mechano-Medicine. Stroke Vasc. Neurol. 5 (2), 185-197. svn2019-000302. doi:10.1136/svn-2019-000302

Chen, Z., Lu, J., Zhang, C., Hsia, I., Yu, X., Marecki, L., et al. (2019). Microclot Array Elastometry for Integrated Measurement of Thrombus Formation and Clot Biomechanics under Fluid Shear. Nat. Commun. 10, 2051. doi:10.1038/ s41467-019-10067-6

Chin, C. D., Linder, V., and Sia, S. K. (2012). Commercialization of Microfluidic point-of-care Diagnostic Devices. Lab. Chip 12, 2118-2134. doi:10.1039/ c2lc21204h

Chiu, D. T., Demello, A. J., Di Carlo, D., Doyle, P. S., Hansen, C., Maceiczyk, R. M., et al. (2017). Small but Perfectly Formed? Successes, Challenges, and
Opportunities for Microfluidics in the Chemical and Biological Sciences. Chem. 2, 201-223. doi:10.1016/j.chempr.2017.01.009

Cines, D. B., and Bussel, J. B. (2021). SARS-CoV-2 Vaccine-Induced Immune Thrombotic Thrombocytopenia. N. Engl. J. Med. 384, 2254-2256. doi:10.1056/ NEJMe2106315

Colman, R. W. (2006). Are Hemostasis and Thrombosis Two Sides of the Same coin? J. Exp. Med. 203, 493-495. doi:10.1084/jem.20060217

Conant, C. G., Schwartz, M. A., Beecher, J. E., Rudoff, R. C., Ionescu-Zanetti, C., and Nevill, J. T. (2011). Well Plate Microfluidic System for Investigation of Dynamic Platelet Behavior under Variable Shear Loads. Biotechnol. Bioeng. 108, 2978-2987. doi:10.1002/bit.23243

Convery, N., and Gadegaard, N. (2019). 30 Years of Microfluidics. Micro Nano Eng. 2, 76-91. doi:10.1016/j.mne.2019.01.003

Costa, P. F., Albers, H. J., Linssen, J. E. A., Middelkamp, H. H. T., Van Der Hout, L., Passier, R., et al. (2017). Mimicking Arterial Thrombosis in a 3D-Printed Microfluidic In Vitro Vascular Model Based on Computed Tomography Angiography Data. Lab. Chip 17, 2785-2792. doi:10.1039/c7lc00202e

Da Luz, L. T., Nascimento, B., Shankarakutty, A. K., Rizoli, S., and Adhikari, N. K. (2014). Effect of Thromboelastography $\left(\right.$ TEG $\left.^{\circledR}\right)$ and Rotational Thromboelastometry $\left(\right.$ ROTEM $\left.^{\circledR}\right)$ on Diagnosis of Coagulopathy, Transfusion Guidance and Mortality in Trauma: Descriptive Systematic Review. Crit. Care 18, 518. doi:10.1186/s13054-014-0518-9

Dahlen, J. R., Price, M. J., Parise, H., and Gurbel, P. A. (2013). Evaluating the Clinical Usefulness of Platelet Function Testing: Considerations for the Proper Application and Interpretation of Performance Measures. Thromb. Haemost. 109, 808-816. doi:10.1160/TH12-08-0608

De Witt, S. M., Swieringa, F., Cavill, R., Lamers, M. M., Van Kruchten, R., Mastenbroek, T., et al. (2014). Identification of Platelet Function Defects by Multi-Parameter Assessment of Thrombus Formation. Nat. Commun. 5, 4257. doi: $10.1038 /$ ncomms5257

Dias, J. D., Lopez-Espina, C. G., Bliden, K., Gurbel, P., Hartmann, J., and Achneck, H. E. (2020). TEG ${ }^{\circledR} 6$ s System Measures the Contributions of Both Platelet Count and Platelet Function to Clot Formation at the Site-Of-Care. Platelets 31, 932-938. doi:10.1080/09537104.2019.1704713

Dlott, J. S., George, R. A., Huang, X., Odeh, M., Kaufman, H. W., Ansell, J., et al. (2014). National Assessment of Warfarin Anticoagulation Therapy for Stroke Prevention in Atrial Fibrillation. Circulation 129, 1407-1414. doi:10.1161/ CIRCULATIONAHA.113.002601

Duke, W. W. (1983). The Relation of Blood Platelets to Hemorrhagic Disease. JAMA 250, 1201-1209. doi:10.1001/jama.250.9.1201

Dupuy, A., Hagimola, L., Mgaieth, N. S. A., Houlahan, C. B., Preketes-Tardiani, R. E., Coleman, P. R., et al. (2021). Thromboinflammation Model-On-A-Chip by Whole Blood Microfluidics on Fixed Human Endothelium. Diagnostics (Basel) 11, 203. doi:10.3390/diagnostics11020203

Dutta, P. K., Zhang, Y., Blanchard, A. T., Ge, C., Rushdi, M., Weiss, K., et al. (2018). Programmable Multivalent DNA-Origami Tension Probes for Reporting Cellular Traction Forces. Nano Lett. 18, 4803-4811. doi:10.1021/ acs.nanolett.8b01374

Favaloro, E. J. (2015). The Platelet Function Analyser (PFA)-100 and von Willebrand disease: a story well over 16 years in the making. Haemophilia 21, 642-645. doi:10.1111/hae.12710

Ferrante, E. A., Blasier, K. R., Givens, T. B., Lloyd, C. A., Fischer, T. J., and Viola, F. (2016). A Novel Device for the Evaluation of Hemostatic Function in Critical Care Settings. Anesth. Analg. 123, 1372-1379. doi:10.1213/ ANE.0000000000001413

Fu, H., Jiang, Y., Yang, D., Scheiflinger, F., Wong, W. P., and Springer, T. A. (2017). Flow-induced elongation of von Willebrand factor precedes tension-dependent activation. Nat. Commun. 8, 324. doi:10.1038/s41467-017-00230-2

Furie, K. L., Cushman, M., Elkind, M. S. V., Lyden, P. D., and Saposnik, G. (2021). American Heart Association/American Stroke Association Stroke Council, LDiagnosis and Management of Cerebral Venous Sinus Thrombosis with Vaccine-Induced Immune Thrombotic Thrombocytopenia. Stroke 52, 2478-2482. doi:10.1161/strokeaha.121.035564

Ganter, M. T., and Hofer, C. K. (2008). Coagulation Monitoring: Current Techniques and Clinical Use of Viscoelastic point-of-care Coagulation Devices. Anesth. Analg. 106, 1366-1375. doi:10.1213/ane.0b013e318168b367

Ginsberg, M. H., Frelinger, A. L., Lam, S. C., Forsyth, J., Mcmillan, R., Plow, E. F., et al. (1990). Analysis of Platelet Aggregation Disorders Based on Flow 
Cytometric Analysis of Membrane Glycoprotein IIb-IIIa with Conformationspecific Monoclonal Antibodies. Blood 76, 2017-2023. doi:10.1182/ blood.v76.10.2017.bloodjournal76102017

Godino, C., Pavon, A. G., Mangieri, A., Viani, G. M., Galaverna, S., Spartera, M., et al. (2014). PlaCor PRT Measurement of Shear-Activated Platelet Aggregate Formation in Stable Patients Treated with Single and Dual Antiplatelet Therapy. Platelets 25, 337-342. doi:10.3109/09537104.2013.825710

Godwin, H. A., and Ginsburg, A. D. (1974). May-Hegglin Anomaly: a Defect in Megakaryocyte Fragmentation? Br. J. Haematol. 26, 117-128. doi:10.1111/ j.1365-2141.1974.tb00455.x

Gorog, D. A., and Jeong, Y. H. (2015). Platelet Function Tests: Why They Fail to Guide Personalized Antithrombotic Medication. J. Am. Heart Assoc. 4, e002094. doi:10.1161/JAHA.115.002094

Gremmel, T., Perkmann, T., Seidinger, D., Koppensteiner, R., Panzer, S., Kopp, C. W., et al. (2013). Differential Impact of Inflammation on Six Laboratory Assays Measuring Residual Arachidonic Acid-Inducible Platelet Reactivity during Dual Antiplatelet Therapy. J. Atheroscler. Thromb. 20, 630-645. doi:10.5551/ jat. 17665

Gubala, V., Harris, L. F., Ricco, A. J., Tan, M. X., and Williams, D. E. (2012). Point of Care Diagnostics: Status and Future. Anal. Chem. 84, 487-515. doi:10.1021/ ac2030199

Guéry, E.-A., Vayne, C., Derray, C., Besombes, J., Lambert, W. C., Rollin, J., et al. (2018). Is There an Alternative to Serotonin Release Assay for the Diagnosis of Heparin Induced Thrombocytopenia (HIT)? Evaluation of 5 Other Functional Methods Using 5B9 a Monoclonal IgG that Mimics HIT Human Antibodies. Blood 132, 3742. doi:10.1182/blood-2018-99-115011

Gutierrez, E., Petrich, B. G., Shattil, S. J., Ginsberg, M. H., Groisman, A., and Kasirer-Friede, A. (2008). Microfluidic Devices for Studies of Shear-dependent Platelet Adhesion. Lab. Chip 8, 1486-1495. doi:10.1039/b804795b

Ha, H., Ziegler, M., Welander, M., Bjarnegård, N., Carlhäll, C. J., Lindenberger, M., et al. (2018). Age-Related Vascular Changes Affect Turbulence in Aortic Blood Flow. Front. Physiol. 9, 36. doi:10.3389/fphys.2018.00036

Hanke, J., Ranke, C., Perego, E., and Köster, S. (2019). Human Blood Platelets Contract in Perpendicular Direction to Shear Flow. Soft Matter 15, 2009-2019. doi:10.1039/c8sm02136h

Hansen, C. E., Qiu, Y., Mccarty, O. J. T., and Lam, W. A. (2018). Platelet Mechanotransduction. Annu. Rev. Biomed. Eng. 20, 253-275. doi:10.1146/ annurev-bioeng-062117-121215

Hao, Z., Lv, H., Tan, R., Yang, X., Liu, Y., and Xia, Y. L. (2021). A Three-Dimensional Microfluidic Device for Monitoring Cancer and Chemotherapy-Associated Platelet Activation. Acs Omega 6, 3164-3172. doi:10.1021/acsomega.0c05572

Harrison, P., and Lordkipanidzé, M. (2013). Testing Platelet Function. Hematol. Oncol. Clin. North. Am. 27, 411-441. doi:10.1016/j.hoc.2013.03.003

Harrison, P., Mackie, I., Mumford, A., Briggs, C., Liesner, R., Winter, M., et al. (2011). Guidelines for the Laboratory Investigation of Heritable Disorders of Platelet Function. Br. J. Haematol. 155, 30-44. doi:10.1111/j.1365-2141.2011.08793.x

Harrison, P., Robinson, M., Liesner, R., Khair, K., Cohen, H., Mackie, I., et al. (2002). The PFA-100: a Potential Rapid Screening Tool for the Assessment of Platelet Dysfunction. Clin. Lab. Haematol. 24, 225-232. doi:10.1046/j.13652257.2002.00451.x

Harrison, P., and Keeling, D. (2012). Platelet Assays and Platelet Dysfunction. Lab. Hematol. Pract., 1. 480-491. doi:10.1002/9781444398595.ch37

Hayward, C. P., Pai, M., Liu, Y., Moffat, K. A., Seecharan, J., Webert, K. E., et al. (2009). Diagnostic Utility of Light Transmission Platelet Aggregometry: Results from a Prospective Study of Individuals Referred for Bleeding Disorder Assessments. J. Thromb. Haemost. 7, 676-684. doi:10.1111/j.15387836.2009.03273.x

Hezard, N., Tessier-Marteau, A., and Macchi, L. (2010). New Insight in Antiplatelet Therapy Monitoring in Cardiovascular Patients: from Aspirin to Thienopyridine. Cardiovasc. Hematol. Disord. Drug Targets 10, 224-233. doi:10.2174/1871529x11006030224

Hu, X., Chen, H., Li, J., Meng, K., Wang, Y., and Li, Y. (2021). A Microfluidic Bleeding Model to Investigate the Effects of Blood Flow Shear on Microvascular Hemostasis. Friction 10 (1), 128-141. doi:10.1007/s40544-020-0470-2

Ilkan, Z., Wright, J. R., Goodall, A. H., Gibbins, J. M., Jones, C. I., and MahautSmith, M. P. (2017). Evidence for Shear-Mediated Ca2+ Entry through Mechanosensitive Cation Channels in Human Platelets and a
Megakaryocytic Cell Line. J. Biol. Chem. 292, 9204-9217. doi:10.1074/ jbc.M116.766196

Jain, A., Graveline, A., Waterhouse, A., Vernet, A., Flaumenhaft, R., and Ingber, D. E. (2016a). A Shear Gradient-Activated Microfluidic Device for Automated Monitoring of Whole Blood Haemostasis and Platelet Function. Nat. Commun. 7, 10176. doi:10.1038/ncomms 10176

Jain, A., Van Der Meer, A. D., Papa, A. L., Barrile, R., Lai, A., Schlechter, B. L., et al. (2016b). Assessment of Whole Blood Thrombosis in a Microfluidic Device Lined by Fixed Human Endothelium. Biomed. Microdevices 18, 73. doi:10.1007/ s10544-016-0095-6

Jakubowski, J. A., Matsushima, N., Asai, F., Naganuma, H., Brandt, J. T., Hirota, T., et al. (2007). A Multiple Dose Study of Prasugrel (CS-747), a Novel Thienopyridine P2Y12 Inhibitor, Compared with Clopidogrel in Healthy Humans. Br. J. Clin. Pharmacol. 63, 421-430. doi:10.1111/j.13652125.2006.02792.x

Jenny, L., Melmer, A., Laimer, M., Hardy, E. T., Lam, W. A., and Schroeder, V. (2020). Diabetes Affects Endothelial Cell Function and Alters Fibrin Clot Formation in a Microvascular Flow Model: A Pilot Study. Diab Vasc. Dis. Res. 17, 1479164120903044. doi:10.1177/1479164120903044

Johnson, G. J., Sharda, A. V., Rao, G. H., Ereth, M. H., Laxson, D. D., and Owen, W. G. (2012). Measurement of Shear-Activated Platelet Aggregate Formation in Non-anticoagulated Blood: Utility in Detection of Clopidogrel-AspirinInduced Platelet Dysfunction. Clin. Appl. Thromb. Hemost. 18, 140-149. doi:10.1177/1076029611423387

Johnston, I., Sarkar, A., Hayes, V., Koma, G. T., Arepally, G. M., Chen, J., et al. (2020). Recognition of PF4-VWF Complexes by Heparin-Induced Thrombocytopenia Antibodies Contributes to Thrombus Propagation. Blood 135, 1270-1280. doi:10.1182/blood.2018881607

Jongen, M. S. A., Macarthur, B. D., Englyst, N. A., and West, J. (2020). Single Platelet Variability Governs Population Sensitivity and Initiates Intrinsic Heterotypic Responses. Commun. Biol. 3, 281. doi:10.1038/s42003-020-1002-5

Jose, B., Mccluskey, P., Gilmartin, N., Somers, M., Kenny, D., Ricco, A. J., et al. (2016). Self-Powered Microfluidic Device for Rapid Assay of Antiplatelet Drugs. Langmuir 32, 2820-2828. doi:10.1021/acs.langmuir.5b03540

Ju, L., Chen, Y., Xue, L., Du, X., and Zhu, C. (2016). Cooperative Unfolding of Distinctive Mechanoreceptor Domains Transduces Force into Signals. Elife 5. 1. doi:10.7554/eLife.15447

Ju, L., Mcfadyen, J. D., Al-Daher, S., Alwis, I., Chen, Y., Tønnesen, L. L., et al. (2018). Compression Force Sensing Regulates Integrin $\alpha \operatorname{IIb} \beta 3$ Adhesive Function on Diabetic Platelets. Nat. Commun. 9, 1087. doi:10.1038/s41467018-03430-6

Kehrel, B. E., and Brodde, M. F. (2013). State of the Art in Platelet Function Testing. Transfus. Med. Hemother. 40, 73-86. doi:10.1159/000350469

Koenig-Oberhuber, V., and Filipovic, M. (2016). New Antiplatelet Drugs and New Oral Anticoagulants. Br. J. Anaesth. 117 (Suppl. 2), ii74-ii84. doi:10.1093/bja/aew214

Korpallová, B., Samoš, M., Bolek, T., Škorňová, I., Kovář, F., Kubisz, P., et al. (2018). Role of Thromboelastography and Rotational Thromboelastometry in the Management of Cardiovascular Diseases. Clin. Appl. Thromb. Hemost. 24, 1199-1207. doi:10.1177/1076029618790092

Koupenova, M., Clancy, L., Corkrey, H. A., and Freedman, J. E. (2018). Circulating Platelets as Mediators of Immunity, Inflammation, and Thrombosis. Circ. Res. 122, 337-351. doi:10.1161/CIRCRESAHA.117.310795

Koupenova, M., Corkrey, H. A., Vitseva, O., Tanriverdi, K., Somasundaran, M., Liu, P., et al. (2021). SARS-CoV-2 Initiates Programmed Cell Death in Platelets. Circ. Res. 129, 631-646. doi:10.1161/CIRCRESAHA.121.319117

Lam, W. A., Chaudhuri, O., Crow, A., Webster, K. D., Li, T. D., Kita, A., et al. (2011). Mechanics and Contraction Dynamics of Single Platelets and Implications for Clot Stiffening. Nat. Mater. 10, 61-66. doi:10.1038/nmat2903

Le Blanc, J., Mullier, F., Vayne, C., and Lordkipanidzé, M. (2020). Advances in Platelet Function Testing-Light Transmission Aggregometry and beyond. J. Clin. Med. 9, 2636. doi:10.3390/jcm9082636

Lee, E. J., Cines, D. B., Gernsheimer, T., Kessler, C., Michel, M., Tarantino, M. D., et al. (2021). Thrombocytopenia Following Pfizer and Moderna SARS-CoV-2 Vaccination. Am. J. Hematol. 96, 534-537. doi:10.1002/ajh.26132

Li, R., Grosser, T., and Diamond, S. L. (2017). Microfluidic Whole Blood Testing of Platelet Response to Pharmacological Agents. Platelets 28, 457-462. doi:10.1080/09537104.2016.1268254 
Li, X. J., and Li, P. C. (2006). Contraction Study of a Single Cardiac Muscle Cell in a Microfluidic Chip. Methods Mol. Biol. 321, 199-225. doi:10.1385/1-59259-9974:199

Liu, L., Zhang, Q., Xiao, S., Sun, Z., Ding, S., Chen, Y., et al. (2021). Inhibition of Shear-Induced Platelet Aggregation by Xueshuantong via Targeting Piezo1 Channel-Mediated Ca2+ Signaling Pathway. Front. Pharmacol. 12, 606245. doi:10.3389/fphar.2021.606245

Lloyd-Donald, P., Churilov, L., Cheong, B., Bellomo, R., Mccall, P. R., Mårtensson, J., et al. (2020). Assessing TEG6S Reliability between Devices and across Multiple Time Points: A Prospective Thromboelastography Validation Study. Sci. Rep. 10, 7045. doi:10.1038/s41598-020-63964-y

Manne, B. K., Denorme, F., Middleton, E. A., Portier, I., Rowley, J. W., Stubben, C., et al. (2020). Platelet Gene Expression and Function in Patients with COVID19. Blood 136, 1317-1329. doi:10.1182/blood.2020007214

Mao, S., Sarkar, A., Wang, Y., Song, C., Levine, D., Wang, X., et al. (2021). Microfluidic Chip Grafted with Integrin Tension Sensors for Evaluating the Effects of Flowing Shear Stress and ROCK Inhibitor on Platelets. Lab. Chip 21, 3128-3136. doi:10.1039/d1lc00259g

Mayr, L. M., and Bojanic, D. (2009). Novel Trends in High-Throughput Screening. Curr. Opin. Pharmacol. 9, 580-588. doi:10.1016/j.coph.2009.08.004

Mcfadyen, J. D., Schaff, M., and Peter, K. (2018). Current and Future Antiplatelet Therapies: Emphasis on Preserving Haemostasis. Nat. Rev. Cardiol. 15, 181-191. doi:10.1038/nrcardio.2017.206

Meagher, R. J., Hatch, A. V., Renzi, R. F., and Singh, A. K. (2008). An Integrated Microfluidic Platform for Sensitive and Rapid Detection of Biological Toxins. Lab. Chip 8, 2046-2053. doi:10.1039/b815152k

Menon, N. V., Su, C., Pang, K. T., Phua, Z. J., Tay, H. M., Dalan, R., et al. (2020). Recapitulating Atherogenic Flow Disturbances and Vascular Inflammation in a Perfusable 3D Stenosis Model. Biofabrication 12, 045009. doi:10.1088/17585090/aba501

Miles, J., Bailey, S. L., Obenaus, A. M., Mollica, M. Y., Usaneerungrueng, C., Byrne, D., et al. (2021). Storage Temperature Determines Platelet GPVI Levels and Function in Mice and Humans. Blood Adv. 5, 3839-3849. doi:10.1182/ bloodadvances.2021004692

Mitrovic, M., Sabljic, N., Cvetkovic, Z., Pantic, N., Zivkovic Dakic, A., Bukumiric, Z., et al. (2021). Rotational Thromboelastometry (ROTEM) Profiling of COVID-19 Patients. Platelets 32, 690-696. doi:10.1080/ 09537104.2021.1881949

Moore, E. E., Moore, H. B., Kornblith, L. Z., Neal, M. D., Hoffman, M., Mutch, N. J., et al. (2021). Trauma-induced Coagulopathy. Nat. Rev. Dis. Primers 7, 30. doi:10.1038/s41572-021-00264-3

Morel-Kopp, M. C., Aboud, M., Tan, C. W., Kulathilake, C., and Ward, C. (2010). Whole Blood Impedance Aggregometry Detects Heparin-Induced Thrombocytopenia Antibodies. Thromb. Res. 125, e234-9. doi:10.1016/ j.thromres.2009.12.001

Muir, A. R., Mcmullin, M. F., Patterson, C., and Mckeown, P. P. (2009). Assessment of Aspirin Resistance Varies on a Temporal Basis in Patients with Ischaemic Heart Disease. Heart 95, 1225-1229. doi:10.1136/hrt.2008.150631

Muthard, R. W., and Diamond, S. L. (2012). Blood Clots Are Rapidly Assembled Hemodynamic Sensors: Flow Arrest Triggers Intraluminal Thrombus Contraction. Arterioscler. Thromb. Vasc. Biol. 32, 2938-2945. doi:10.1161/ ATVBAHA.112.300312

Muthard, R. W., and Diamond, S. L. (2013). Side View Thrombosis Microfluidic Device with Controllable wall Shear Rate and Transthrombus Pressure Gradient. Lab. Chip 13, 1883-1891. doi:10.1039/c3lc41332b

Myers, D. R., Qiu, Y., Fay, M. E., Tennenbaum, M., Chester, D., Cuadrado, J., et al. (2017). Single-platelet Nanomechanics Measured by High-Throughput Cytometry. Nat. Mater. 16, 230-235. doi:10.1038/nmat4772

Nesbitt, W. S., Mangin, P., Salem, H. H., and Jackson, S. P. (2006). The Impact of Blood Rheology on the Molecular and Cellular Events Underlying Arterial Thrombosis. J. Mol. Med. (Berl) 84, 989-995. doi:10.1007/s00109-006-0101-1

Nesbitt, W. S., Westein, E., Tovar-Lopez, F. J., Tolouei, E., Mitchell, A., Fu, J., et al. (2009). A Shear Gradient-dependent Platelet Aggregation Mechanism Drives Thrombus Formation. Nat. Med. 15, 665-673. doi:10.1038/nm.1955

Ono, A., Westein, E., Hsiao, S., Nesbitt, W. S., Hamilton, J. R., Schoenwaelder, S. M., et al. (2008). Identification of a Fibrin-independent Platelet Contractile Mechanism Regulating Primary Hemostasis and Thrombus Growth. Blood 112, 90-99. doi:10.1182/blood-2007-12-127001
Opheim, E. N., Apelseth, T. O., Stanworth, S. J., Eide, G. E., and Hervig, T. (2019). Multiple Electrode Aggregometry and Thromboelastography in Thrombocytopenic Patients with Haematological Malignancies. Blood Transfus. 17, 181-190. doi:10.2450/2018.0140-18

Osdoit, S., and Rosa, J. P. (2001). Fibrin Clot Retraction by Human Platelets Correlates with alpha(IIb)beta(3) Integrin-dependent Protein Tyrosine Dephosphorylation. J. Biol. Chem. 276, 6703-6710. doi:10.1074/ jbc.M008945200

Pakala, R., and Waksman, R. (2011). Currently Available Methods for Platelet Function Analysis: Advantages and Disadvantages. Cardiovasc. Revasc Med. 12, 312-322. doi:10.1016/j.carrev.2010.09.005

Paniccia, R., Priora, R., Liotta, A. A., and Abbate, R. (2015). Platelet Function Tests: a Comparative Review. Vasc. Health Risk Manag. 11, 133-148. doi:10.2147/ VHRM.S44469

Panzer, S., and Jilma, P. (2011). Methods for Testing Platelet Function for Transfusion Medicine. Vox Sang 101, 1-9. doi:10.1111/j.14230410.2011.01467.x

Pavord, S., Scully, M., Hunt, B. J., Lester, W., Bagot, C., Craven, B., et al. (2021). Clinical Features of Vaccine-Induced Immune Thrombocytopenia and Thrombosis. N. Engl. J. Med. 385. 1680-1689. doi:10.1056/nejmoa2109908

Peshkova, A. D., Evdokimova, T. A., Sibgatullin, T. B., Ataullakhanov, F. I., Litvinov, R. I., and Weisel, J. W. (2020). Accelerated Spatial Fibrin Growth and Impaired Contraction of Blood Clots in Patients with Rheumatoid Arthritis. Int. J. Mol. Sci. 21, 9434. doi:10.3390/ijms21249434

Podrez, E. A., Byzova, T. V., Febbraio, M., Salomon, R. G., Ma, Y., Valiyaveettil, M., et al. (2007). Platelet CD36 Links Hyperlipidemia, Oxidant Stress and a Prothrombotic Phenotype. Nat. Med. 13, 1086-1095. doi:10.1038/nm1626

Rasche, H. (2001). Haemostasis and Thrombosis: an Overview. Eur. Heart J. Supplements 3, Q3-Q7. doi:10.1016/s1520-765x(01)90034-3

Reddy, E. C., Wang, H., Christensen, H., Mcmillan-Ward, E., Israels, S. J., Bang, K. W. A., et al. (2018). Analysis of Procoagulant Phosphatidylserine-Exposing Platelets by Imaging Flow Cytometry. Res. Pract. Thromb. Haemost. 2, 736-750. doi:10.1002/rth2.12144

Rogasi, P. G., Paniccia, R., Coppo, M., Prisco, D., Boddi, M., Chen, J., et al. (1988). Radioimmunoassay of Thromboxane B2 in Plasma: Methodological Modifications. Thromb. Res. 51, 533-541. doi:10.1016/0049-3848(88) 90118-1

Rossi, J. M., and Diamond, S. L. (2020). Scalable Manufacture of a Disposable, Storage-Stable Eight-Channel Microfluidic Device for Rapid Testing of Platelet, Coagulation, and Drug Function under Whole Blood Flow. Biomicrofluidics 14, 054103. doi:10.1063/5.0023312

Ruggeri, Z. M. (2002). Platelets in Atherothrombosis. Nat. Med. 8, 1227-1234. doi:10.1038/nm1102-1227

Santilli, F., Vazzana, N., Liani, R., Guagnano, M. T., and Davì, G. (2012). Platelet Activation in Obesity and Metabolic Syndrome. Obes. Rev. 13, 27-42. doi:10.1111/j.1467-789X.2011.00930.x

Savage, B., Saldívar, E., and Ruggeri, Z. M. (1996). Initiation of platelet adhesion by arrest onto fibrinogen or translocation on von Willebrand factor. Cell 84, 289-297. doi:10.1016/s0092-8674(00)80983-6

Savion, N., and Varon, D. (2006). Impact--the Cone and Plate(let) Analyzer: Testing Platelet Function and Anti-platelet Drug Response. Pathophysiol. Haemost. Thromb. 35, 83-88. doi:10.1159/000093548

Sharma, S., Zapatero-Rodríguez, J., Estrela, P., and O'kennedy, R. (2015). Point-of-Care Diagnostics in Low Resource Settings: Present Status and Future Role of Microfluidics. Biosensors (Basel) 5, 577-601. doi:10.3390/ bios5030577

Shcherbina, A., Cooley, J., Lutskiy, M. I., Benarafa, C., Gilbert, G. E., and RemoldO'donnell, E. (2010). WASP Plays a Novel Role in Regulating Platelet Responses Dependent on alphaIIbbeta3 Integrin Outside-In Signalling. Br. J. Haematol. 148, 416-427. doi:10.1111/j.1365-2141.2009.07959.x

Shen, R. F., and Tai, H. H. (1986). Monoclonal Antibodies to Thromboxane Synthase from Porcine Lung. Production and Application to Development of a Tandem Immunoradiometric Assay. J. Biol. Chem. 261, 11585-11591. doi:10.1016/s0021-9258(18)67283-7

Shenkman, B., Matetzky, S., Fefer, P., Hod, H., Einav, Y., Lubetsky, A., et al. (2008). Variable Responsiveness to Clopidogrel and Aspirin Among Patients with Acute Coronary Syndrome as Assessed by Platelet Function Tests. Thromb. Res. 122, 336-345. doi:10.1016/j.thromres.2007.10.018 
Sheriff, J., Soares, J. S., Xenos, M., Jesty, J., Slepian, M. J., and Bluestein, D. (2013). Evaluation of Shear-Induced Platelet Activation Models under Constant and Dynamic Shear Stress Loading Conditions Relevant to Devices. Ann. Biomed. Eng. 41, 1279-1296. doi:10.1007/s10439-013-0758-x

Sibbing, D., Schulz, S., Braun, S., Morath, T., Stegherr, J., Mehilli, J., et al. (2010). Antiplatelet Effects of Clopidogrel and Bleeding in Patients Undergoing Coronary Stent Placement. J. Thromb. Haemost. 8, 250-256. doi:10.1111/ j.1538-7836.2009.03709.x

Solomon, C., Hartmann, J., Osthaus, A., Schöchl, H., Raymondos, K., Koppert, W., et al. (2010). Platelet Concentrates Transfusion in Cardiac Surgery in Relation to Preoperative point-of-care Assessment of Platelet Adhesion and Aggregation. Platelets 21, 221-228. doi:10.3109/09537100903560155

Stravitz, R. T. (2012). Potential Applications of Thromboelastography in Patients with Acute and Chronic Liver Disease. Gastroenterol. Hepatol. (N Y) 8, 513-520.

Szydzik, C., Brazilek, R. J., Akbaridoust, F., De Silva, C., Moon, M., Marusic, I., et al. (2019). Active Micropump-Mixer for Rapid Antiplatelet Drug Screening in Whole Blood. Anal. Chem. 91, 10830-10839. doi:10.1021/acs.analchem.9b02486

Tantry, U. S., Bonello, L., Aradi, D., Price, M. J., Jeong, Y.-H., Angiolillo, D. J., et al. (2013). Working Group on On-Treatment Platelet, RConsensus and Update on the Definition of On-Treatment Platelet Reactivity to Adenosine Diphosphate Associated with Ischemia and Bleeding. J. Am. Coll. Cardiol. 62, 2261-2273. doi:10.1016/j.jacc.2013.07.101

Thachil, J. (2016). Antiplatelet Therapy - a Summary for the General Physicians. Clin. Med. (Lond) 16, 152-160. doi:10.7861/clinmedicine.16-2-152

Ting, L., Feghhi, S., Karchin, A., Tooley, W., White, N. J., and Sniadecki, N. (2013). ClotOn-A-Chip: A Microfluidic Device to Study Platelet Aggregation and Contractility under Shear. Blood 122, 2363. doi:10.1182/blood.v122.21.2363.2363

Ting, L. H., Feghhi, S., Taparia, N., Smith, A. O., Karchin, A., Lim, E., et al. (2019). Contractile Forces in Platelet Aggregates under Microfluidic Shear Gradients Reflect Platelet Inhibition and Bleeding Risk. Nat. Commun. 10, 1204. doi:10.1038/s41467-019-09150-9

Tovar-Lopez, F. J., Rosengarten, G., Westein, E., Khoshmanesh, K., Jackson, S. P., Mitchell, A., et al. (2010). A Microfluidics Device to Monitor Platelet Aggregation Dynamics in Response to Strain Rate Micro-gradients in Flowing Blood. Lab. Chip 10, 291-302. doi:10.1039/b916757a

Tsai, M., Kita, A., Leach, J., Rounsevell, R., Huang, J. N., Moake, J., et al. (2012). In Vitro modeling of the Microvascular Occlusion and Thrombosis that Occur in Hematologic Diseases Using Microfluidic Technology. J. Clin. Invest. 122, 408-418. doi:10.1172/JCI58753

Van Rooij, B. J. M., Závodszky, G., Hoekstra, A. G., and Ku, D. N. (2020). Biorheology of Occlusive Thrombi Formation under High Shear: In Vitro Growth and Shrinkage. Sci. Rep. 10, 18604. doi:10.1038/s41598-020-74518-7

Varble, N., Trylesinski, G., Xiang, J., Snyder, K., and Meng, H. (2017). Identification of Vortex Structures in a Cohort of 204 Intracranial Aneurysms. J. R. Soc. Interf. 14, 20170021. doi:10.1098/rsif.2017.0021

Walenga, J. M., Thethi, I., and Lewis, B. E. (2012). Nonhemostatic Adverse Effects of Anticoagulants and Antiplatelet Agents. Semin. Thromb. Hemost. 38, 884-892. doi:10.1055/s-0032-1325615

Westein, E., Van Der Meer, A. D., Kuijpers, M. J., Frimat, J. P., Van Den Berg, A., and Heemskerk, J. W. (2013). Atherosclerotic geometries exacerbate pathological thrombus formation poststenosis in a von Willebrand factor-dependent manner. Proc. Natl. Acad. Sci. U S A. 110, 1357-1362. doi:10.1073/pnas.1209905110

Williams, C. D., Cherala, G., and Serebruany, V. (2010). Application of Platelet Function Testing to the Bedside. Thromb. Haemost. 103, 29-33. doi:10.1160/TH09-06-0375
Yarovoi, H. V., Kufrin, D., Eslin, D. E., Thornton, M. A., Haberichter, S. L., Shi, Q. et al. (2003). Factor VIII Ectopically Expressed in Platelets: Efficacy in Hemophilia A Treatment. Blood 102, 4006-4013. doi:10.1182/blood-200305-1519

Yin, W., Shanmugavelayudam, S. K., and Rubenstein, D. A. (2011). The Effect of Physiologically Relevant Dynamic Shear Stress on Platelet and Endothelial Cell Activation. Thromb. Res. 127, 235-241. doi:10.1016/ j.thromres.2010.11.021

Zaky, A. (2017). Thromboelastometry versus Rotational Thromboelastography in Cardiac Surgery. Semin. Cardiothorac. Vasc. Anesth. 21, 206-211. doi:10.1177/ 1089253217697146

Zhang, C., and Neelamegham, S. (2017). Application of Microfluidic Devices in Studies of Thrombosis and Hemostasis. Platelets 28, 434-440. doi:10.1080/ 09537104.2017.1319047

Zhang, Y., Qiu, Y., Blanchard, A. T., Chang, Y., Brockman, J. M., Ma, V. P., et al. (2018). Platelet Integrins Exhibit Anisotropic Mechanosensing and Harness Piconewton Forces to Mediate Platelet Aggregation. Proc. Natl. Acad. Sci. US A. 115, 325-330. doi:10.1073/pnas.1710828115

Zhang, Y., Ramasundara, S. Z., Preketes-Tardiani, R. E., Cheng, V., Lu, H., and Ju, L. A. (2021). Emerging Microfluidic Approaches for Platelet Mechanobiology and Interplay with Circulatory Systems. Front. Cardiovasc. Med. 8, 766513. doi: $10.3389 /$ fcvm.2021.766513

Zhao, Y. C., Vatankhah, P., Goh, T., Michelis, R., Kyanian, K., Zhang, Y., et al. (2021). Hemodynamic Analysis for Stenosis Microfluidic Model of Thrombosis with Refined Computational Fluid Dynamics Simulation. Sci. Rep. 11, 6875. doi:10.1038/s41598-021-86310-2

Zhao, Y., Wetter, N. M., and Wang, X. (2019). Imaging Integrin Tension and Cellular Force at Submicron Resolution with an Integrative Tension Sensor. J. Vis. Exp. 146. e59476. doi:10.3791/59476

Zilberman-Rudenko, J., Sylman, J. L., Lakshmanan, H. H. S., Mccarty, O. J. T., and Maddala, J. (2017). Dynamics of Blood Flow and Thrombus Formation in a Multi-Bypass Microfluidic Ladder Network. Cel. Mol. Bioeng. 10, 16-29. doi:10.1007/s12195-016-0470-7

Zöller, B., Li, X., Sundquist, J., and Sundquist, K. (2012). Autoimmune Diseases and Venous Thromboembolism: a Review of the Literature. Am. J. Cardiovasc. Dis. 2, 171-183.

Conflict of Interest: The authors declare that the research was conducted in the absence of any commercial or financial relationships that could be construed as a potential conflict of interest.

Publisher's Note: All claims expressed in this article are solely those of the authors and do not necessarily represent those of their affiliated organizations, or those of the publisher, the editors and the reviewers. Any product that may be evaluated in this article, or claim that may be made by its manufacturer, is not guaranteed or endorsed by the publisher.

Copyright (c) 2022 Zhang, Jiang, Chen and Ju. This is an open-access article distributed under the terms of the Creative Commons Attribution License (CC $B Y$ ). The use, distribution or reproduction in other forums is permitted, provided the original author(s) and the copyright owner(s) are credited and that the original publication in this journal is cited, in accordance with accepted academic practice. No use, distribution or reproduction is permitted which does not comply with these terms. 